\title{
Microstructural and Kinetic Studies of Reverse Transformation in a Low-carbon Low Alloy Steel*
}

\author{
By Shöichi MATSUDA $A^{* *}$ and Yoshihiro OKAMURA OH* $^{* *}$
}

\section{Synopsis}

The process of the formation of austenite in the early stage of reverse transformation was studied in a low-carbon low alloy steel with acicular structures such as martensite, bainite, and tempered martensite.

Austenite grains were divided into two types: The globular and the acicular. Globular austenite grains were formed always accompanying the dissolution of cementite, whereas the formation of acicular austenite grains did not accompany the dissolution of cementite, and most acicular austenite grains had the same orientation in a prior austenite grains.

Based upon these results, mechanisms of the formation of both types of austenite grains were discussed. It was concluded that the rate controlling step of the formation of globular austenite grain was the diffusion of carbon in austenite, and that acicular austenite grain was formed by the martensitic reverse transformation.

\section{Introduction}

The toughness of steel has long been known to improve by austenite grain refinement. Grange ${ }^{1,2)}$ was the first to devise a method of producing significantly fine austenite grain: it was by repeating rapid heating of acicular structures into the lower end of the singlephase austenite range. Commercial exploitation of his method is, however, somewhat limited today because of practical and economical difficulties.

In applying the phase transformation method of austenite grain refinement to practical uses, there are several problems that must be solved. These are summarized as follows.

(1) What is the mechanism of nucleation and growth of austenite at the prior austenite grain boundaries and in grains?

(2) What are the factors that contribute to the growth kinetics of austenite grains?

In relation to these problems, several investigators $^{3-8)}$ found that acicular austenite grains are formed in the early stage of austenitization of steels with martensite structure. Furthermore D'Yachenko' ${ }^{9}$ confirmed in a $0.6 \% \mathrm{C}$ steel that there exists $(111)_{r} / /$ $(110)_{\alpha}$ orientation relationship between the austenite formed on passing over $\mathrm{A}_{\mathrm{C} 1}$ and the initial martensite. Homma $^{10)}$ recently studied the process of the formation of austenite of Ni-Cr-Mo steel with martensitic structure and deduced that austenite grain size formed above the $\mathrm{A}_{\mathrm{C} 3}$ temperature is related to the distribution of the crystallographic orientation of acicular austenite grains. However, quantitative analysis of the formation of austenite was not done in these works and the idea that can be applied to the austenite grain refinement in practice was not involved.

The purpose of the present paper is twofold: one is to understand systematically the early stage of the reverse transformation, and the other to explore possibilities of producing fine austenite grains by means other than those which have already been reported.

\section{Experimental Procedures}

The chemical composition of the vacuum melted low-carbon low alloy steel are shown in Table 1, together with the $\mathrm{A}_{\mathrm{C} 1}$ and $\mathrm{A}_{\mathrm{C} 3}$ temperatures. Ingot of $20 \mathrm{~kg}$ in weight was heated at $1250^{\circ} \mathrm{C}$ for $1 \mathrm{hr}$ in a furnace under an argon atmosphere and was hot rolled to $13 \mathrm{~mm}$ thick plate. After machining to $10 \times 10 \times$ $55 \mathrm{~mm}$ square lumbers, they were sealed in quartz capsules containing an argon atmosphere and homogenized at $1350^{\circ} \mathrm{C}$ for $1 \mathrm{hr}$.

To obtain acicular structures, such as martensite, bainite, and tempered martensite, heat treatments shown in Table 2 were employed. The specimens with the size of $10 \mathrm{~mm}$ in length and $3 \mathrm{~mm}$ in diameter were prepared by machining the heat treated square lumbers.

In order to study the process of the formation of austenite, specimens with acicular structures were rapidly heated to temperatures of $700^{\circ}, 720^{\circ}$, and $740^{\circ} \mathrm{C}$, and the isothermal reverse transformation was discontinued by quenching after predetermined periods of time. Another set of specimens was heated to $700^{\circ} \mathrm{C}$, just above the $\mathrm{A}_{\mathrm{C} 1}$ temperature, with widely varied heating rates $\left(1.7 \sim 3000^{\circ} \mathrm{C} / \mathrm{min}\right)$ and quenched immediately after heating.

All specimens were prepared for metallographic examination by mechanical polishing and by etching with $2 \%$ picral. For transmission electron microscopic study, which was performed to determine the crystal-

Table 1. Chemical composition (wt \%) and transformation temperature $\left({ }^{\circ} \mathrm{C}\right)$ of steel

\begin{tabular}{ccccccccc}
$\mathrm{C}$ & $\mathrm{Si}$ & $\mathrm{Mn}$ & $\mathrm{Ni}$ & $\mathrm{Mo}$ & $\mathrm{Al}$ & $\mathrm{B}$ & $\mathrm{A}_{\mathrm{C} 1}$ & $\mathrm{~A}_{\mathrm{C} 3}$ \\
\hline 0.12 & 0.20 & 0.50 & 3.50 & 0.35 & 0.01 & $<0.0005$ & 694 & 802
\end{tabular}

Table 2. Heat treatments to obtain acicular structures such as martensite, bainite and tempered martensite

\begin{tabular}{l|lc}
\hline Symbol & Structure & Heat treatment \\
\hline $\mathrm{M}$ & Martensite & $1300^{\circ} \mathrm{C} \times 30 \mathrm{~min}(\mathrm{WQ})$ \\
$\mathrm{F} / \mathrm{Cem}$ & $\begin{array}{c}\text { Tempered } \\
\text { martensite }\end{array}$ & $\begin{array}{c}1300^{\circ} \mathrm{C} \times 30 \mathrm{~min}(\mathrm{WQ}) \\
+600^{\circ} \mathrm{C} \times 40 \mathrm{hr}(\mathrm{AC})\end{array}$ \\
$\mathrm{B}$ & Bainite & $1300^{\circ} \mathrm{C} \times 30 \mathrm{~min} \mathrm{~Pb}\left(420^{\circ} \mathrm{C}\right) \mathrm{Q}$ \\
\hline
\end{tabular}

* Received February 18, 1974.

** Fundametnal Research Laboratories, Nippon Steel Corp., 1618, Ida, Nakahara-ku, Kawasaki 211.

*** Yawata Works, Nippon Steel Corp., Edamitsu, Yawata-ku, Kitakyūshū 805. 


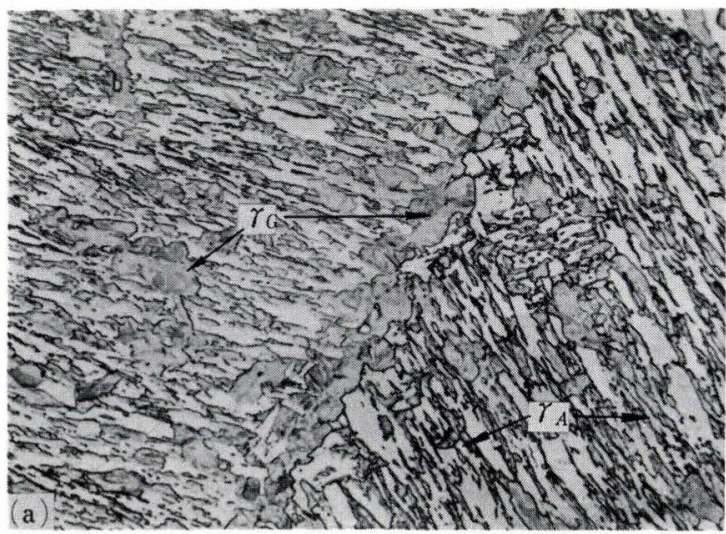

Martensite

$\begin{array}{ll}\text { Martensite } & \text { Tempered martensite } \\ \text { Heating rate: } \quad 100^{\circ} \mathrm{C} / \mathrm{sec} ; \gamma_{G}: \text { globular austenite; } \gamma_{A}: \text { acicular austenite }\end{array}$

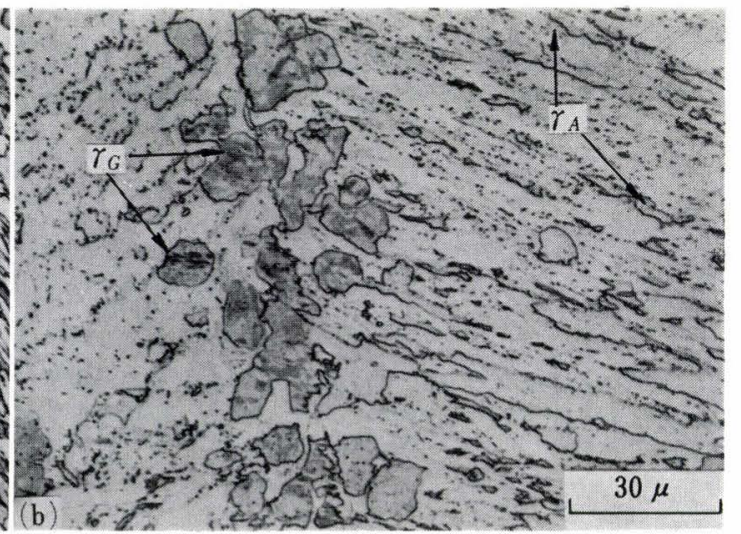

Tempered martensite
: acicular austenite lographic orientation relationship between reverse austenite and martensite, a $9 \% \mathrm{Ni}$ steel* with $1 \mathrm{~mm}$ in thickness was used. The specimens were reduced to $30 \mu$ thick foil by chemical etching with an reagent of phosphoric acid and hydrogen peroxide. Final thinning was accomplished with a modified Bollman technique in an electrolyte of chromium trioxide and phosphoric acid.

\section{Results}

\section{Shape and Growth Rate of Austenite}

Photographs 1 (a) and (b) show the microstructures which were obtained by isothermal reverse transformation at $720^{\circ} \mathrm{C}$ for $10 \mathrm{sec}$ and water quenched. Initial microstructure was martensite in Photo. 1 (a) and tempered martensite in Photo. 1 (b). From the observation of these photographs, it can be seen that austenite grains that are formed in the early stage of austenitization may be divided into two types: globular and acicular. It will be noticed that, along prior austenite grain boundaries, only the globular austenite grains are formed, whereas, within prior austenite grains both types are formed. The number of globular austenite grains, which were formed within grains, depended on initial microstructures, decreasing in the order of martensite, bainite, and tempered martensitic structures. From the other experimental result, it was found that the number of globular austenite grains also decreased as the isothermal transformation temperature was lowered.

Photograph 2 shows the microstructure of specimen held isothermally at $720^{\circ} \mathrm{C}$ for $10 \mathrm{sec}$, with special reference to the cementite particle size existing in globular austenite grain. From this photograph, it can be seen that the formation of globular austenite grains always accompany the dissolution of cementite.

Figures 1 (a) and (b) show a linear relation between logarithms of the radius of globular austenite grain and the isothermal transformation time (full line). From the slope of straight lines, an empirical equation can be presented as

$$
R=K t^{1 / 2}
$$

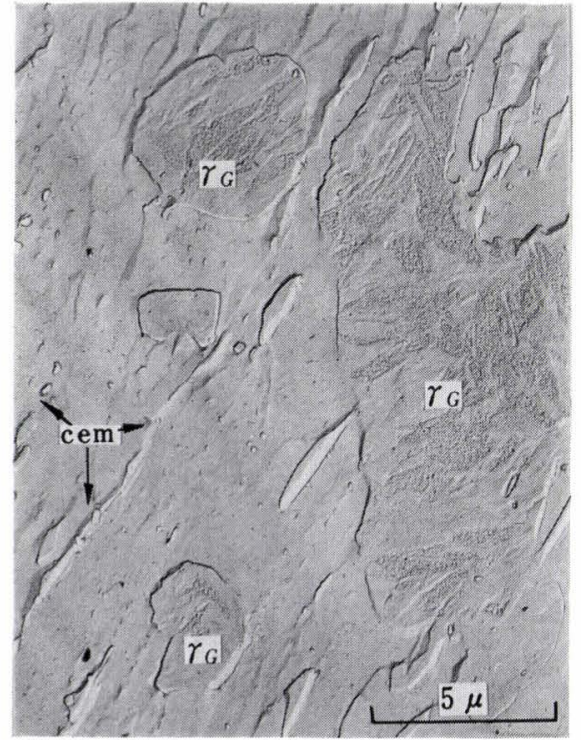

Initial structure: tempered martensite $\gamma_{G}:$ globular austenite cem: cementite Heating rate: $100^{\circ} \mathrm{C} / \mathrm{sec}$

Photo. 2. Microstructure of a specimen held isothermally at $720^{\circ} \mathrm{C}$ for $10 \mathrm{sec}$ (raplica)

where, $\quad R$ : radius of globular austenite

$t$ : isothermal transformation time

$K$ : growth parameter.

These results shown in Photo. 2 (a) and Eq. (1) strongly suggest that the reaction is controlled by volume diffusion and that the rate of the dissolution of cementite is diffusion-controlled.

Growth of globular austenite grains was arrested by mutual impingement of these grains, and the final size of grain formed along prior austenite grain boundaries was smaller than that within grains (dotted line). This is due to the difference of the number of austenite nuclei between grain boundaries and grain matrix.

It is to be noted that the growth parameter in tempered martensitic structure is smaller than that of martensitic or bainitic structure. In relation to this

* It had already been confirmed by the present authors that the process of reverse transformation of the $3.5 \% \mathrm{Ni}$ steel is the same as that of the $9 \% \mathrm{Ni}$ steel. Therefore, it may reasonably be assumed that the crystallographic characteristics are also the same in both steels. 

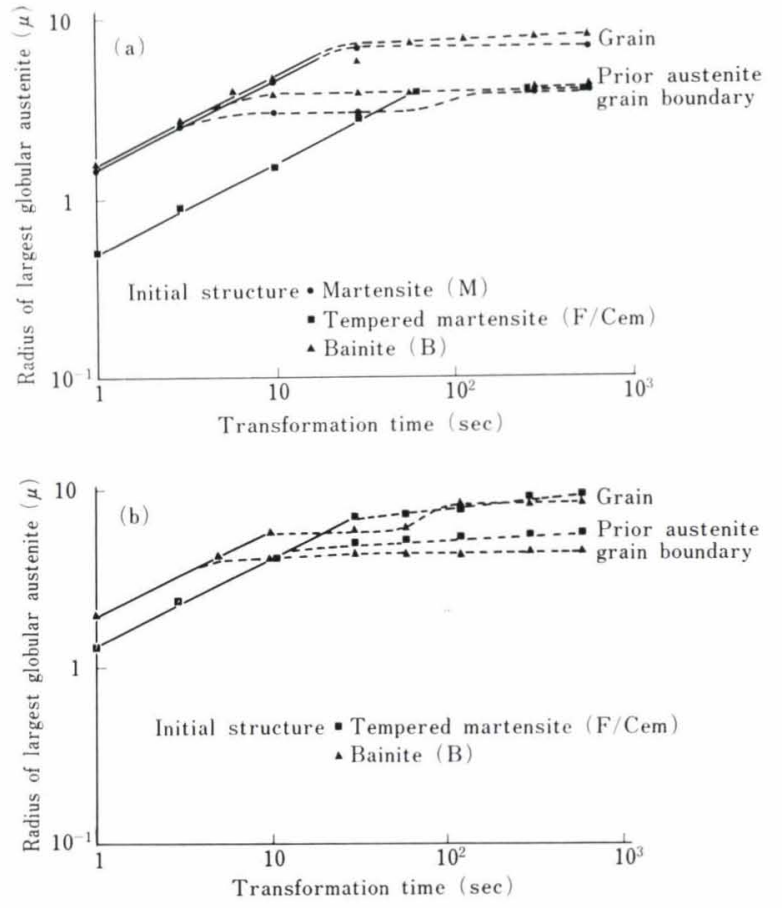

Fig. 1. Radius of globular austenite as a function of transformation time

(a) Isothermal transformation temperature: $700^{\circ} \mathrm{C}$

(b) Isothermal transformation temperature: $720^{\circ} \mathrm{C}$

kinetic result, compositions of cementite existing in initial microstructures are shown in Table 3 . As clearly seen from this table, manganese in tempered martensitic structure segregates to cementite in the ratio of about 9 parts in cementite to 1 part in the matrix, but in martensite and bainitic structures manganese does not segregate to cementite. These results suggest the possibility that the small value of $K$ in tempered martensite is due to difficulty of the dissolution of cementite by segregating manganese.

Photograph 3 shows the microstructures of a specimen held isothermally at $720^{\circ} \mathrm{C}$ for $10 \mathrm{sec}$, with special reference to acicular austenite grains. Microstructural features observed in this photograph are summarized as follows.

(1) Lengthwise direction of acicular austenite grains is parallel to the martensite lath boundaries.

(2) The formation of acicular austenite grains does not accompany the dissolution of cementite, in contrast with Photo. 2 which shows that globular austenite grains are always formed accompanying the dissolution of cementite.

Photograph 4 represents the transmission electron microscopic studies made on a $9 \% \mathrm{Ni}$ steel. Photograph 4 (a) indicates the presence of martensite laths intermixed with small regions of darker contrast (arrows). The presence of reverse austenite in these regions was difinitely established by the dark field image (Photo. 4 (b)) taken with $(02 \overline{2})_{r}$ reflection in the diffraction patterns (Photo. 4 (c)). As shown in Photos. 4 (b) and (c), acicular austenite grains have nearly the same orientation one another, and the crystallographic orientation relationship between reverse austenite and martensite can be represented by
Table 3. Chemical composition of cementite (wt \%)

\begin{tabular}{l|ccc}
\hline Symbol & $\mathrm{Mn}$ & $\mathrm{Ni}$ & $\mathrm{Fe}$ \\
\hline \multirow{2}{*}{$\mathrm{M}$} & 0.50 & 3.50 & 96.00 \\
& $(1.00)$ & $(1.00)$ & \\
\multirow{2}{*}{ F/Cem } & 4.55 & 1.77 & 93.68 \\
& $(9.10)$ & $(0.50)$ & \\
$\mathrm{B}$ & 0.73 & 3.68 & 95.59 \\
& $(1.46)$ & $(1.04)$ &
\end{tabular}

Figures in parenthesis: (Mn, Ni) $)_{\text {cem }} /(\mathrm{Mn}, \mathrm{Ni})_{\text {matrix }}$

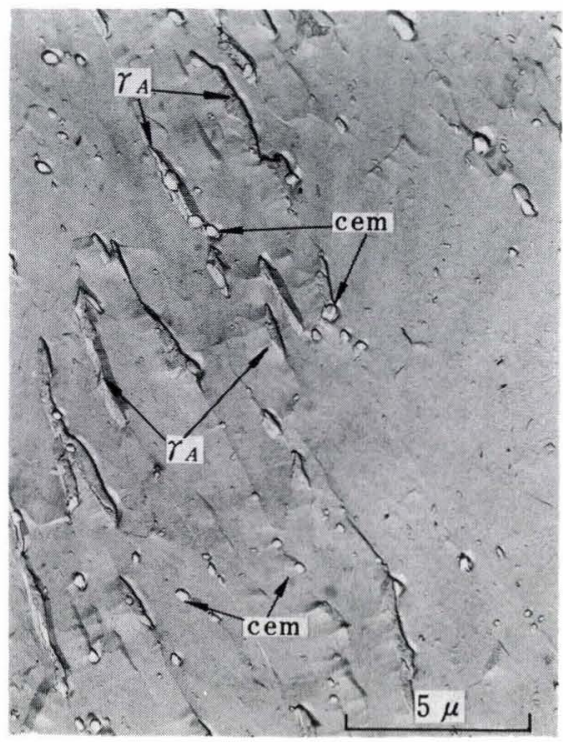

Initial structure: tempered martensite $\gamma_{A}:$ acicular austenite cem: Cementite Heating rate: $100^{\circ} \mathrm{C} / \mathrm{sec}$

Photo. 3. Microstructure of a specimen held isothermally at $720^{\circ} \mathrm{C}$ for $10 \mathrm{sec}$ (replica)

$(\overline{1} 10)_{\gamma} / /(\overline{1} 1 \overline{1})_{\alpha}$

$[11 \overline{2}]_{\gamma} / /[1 \overline{1} \overline{2}]_{\alpha}$

This orientation relationship is in accord with Kurdjumov-Sachs relation.

From these results it is suggested that acicular austenite grains are formed by the martensitic reverse transformation obeying $\mathrm{K}-\mathrm{S}$ orientation relationship.

\section{Relation between Shape of Austenite Grains and Heat- ing Rates}

The effect of heating rate on the microstructures formed in the early stage of austenitization was examined. Photographs 5 (a) and (b) show the microstructures obtained by quenching immediately after heating to $700^{\circ} \mathrm{C}$ with widely varied heating rates (1.7 to $\left.3000^{\circ} \mathrm{G} / \mathrm{min}\right)$. Figure 2 shows the analytical result of Photo. 5, which represents the relation between the number of globular austenite grains and heating rates. From these result it can be seen that the number of globular austenite grains decreases as heating rate decreases, and that this type of grain can not be formed for heating rates slower than $1.7^{\circ} \mathrm{C} / \mathrm{min}$.

In relation to the results shown in Photo. 5 and Fig. 2, the dependence of the compositions of cementite on heating rate is shown in Table 4 . In this case all specimens were heated to a temperature just below 

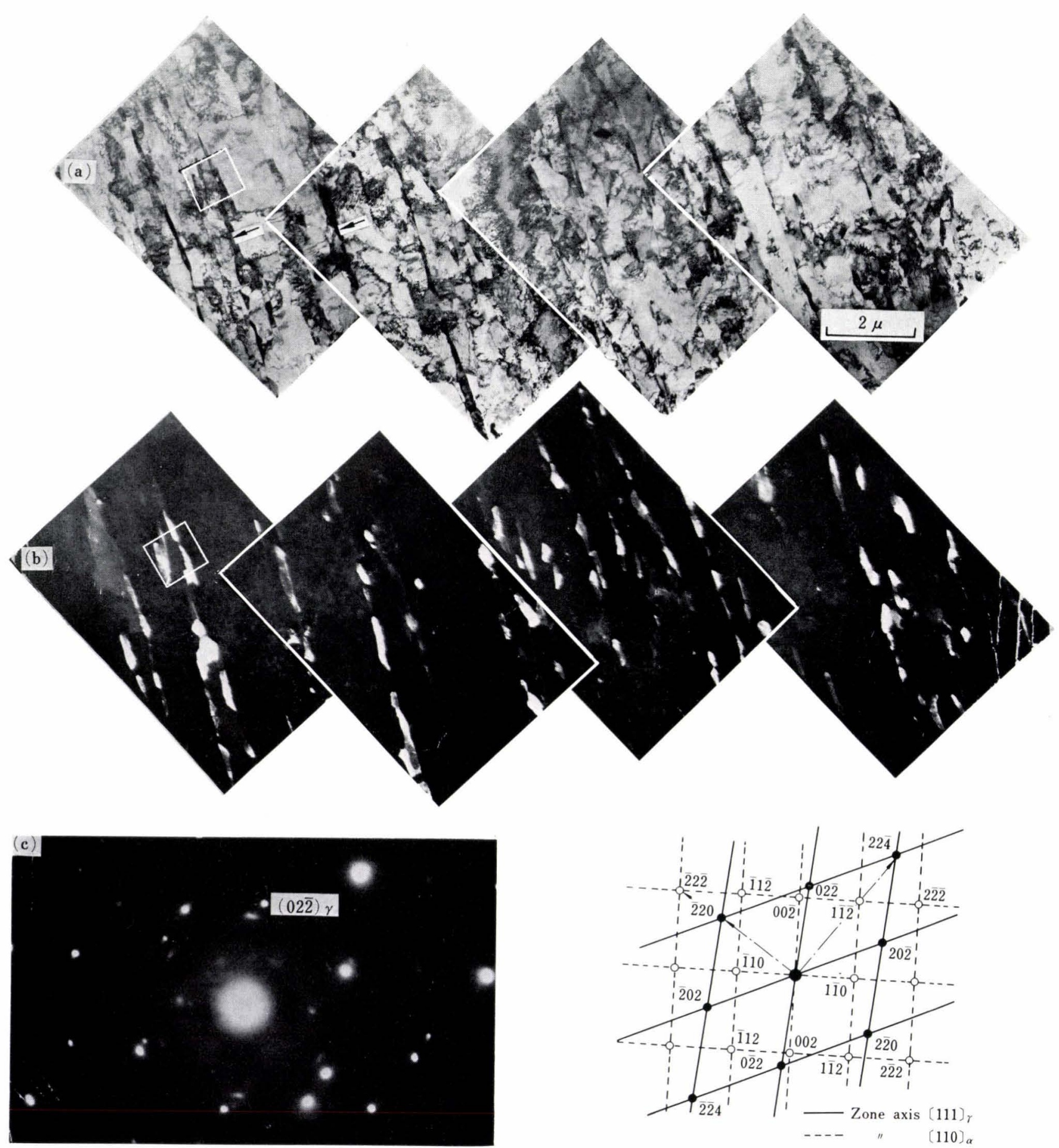

Photo. 4. Analysis of crystallographic characteristics of reverse austenite in $9 \% \mathrm{Ni}$ steel (Transmission electron micrograph)
(a) Bright-field image
(b) Dark-field image
(c) Diffraction patterns from the framed area in (a) and indexing of diffraction patterns

the $\mathrm{A}_{\mathrm{C} 1}$ temperature and quenched immediately afterwards. The segregation of manganese to cementite takes place as the heating rate is lowered. The accompanying decrease in the number of austenite grain is likely due to the retardation of growth by the segregation as revealed in Table 3 .

\section{Discussion}

\section{Mechanism of Formation of Globular Austenite}

Judging from the experimental results that the para- bolic relation exists between the radius of globular austenite and isothermal transformation time (Eq. (1)) and that the formation of these austenite grains always accompany the dissolution of cementite, it is considered that the rate of growth of globular austenite is controlled by the rate of dissolution of cementite as shown in Fig. 3. This type of reaction has recently been proposed by Judd ${ }^{11}$ and Hillert ${ }^{12}$ ) for calculating the austenitizing process from a steel in a soft annealed condition. The rate-controlling process is the diffusion of carbon through austenite grain, and the radius 

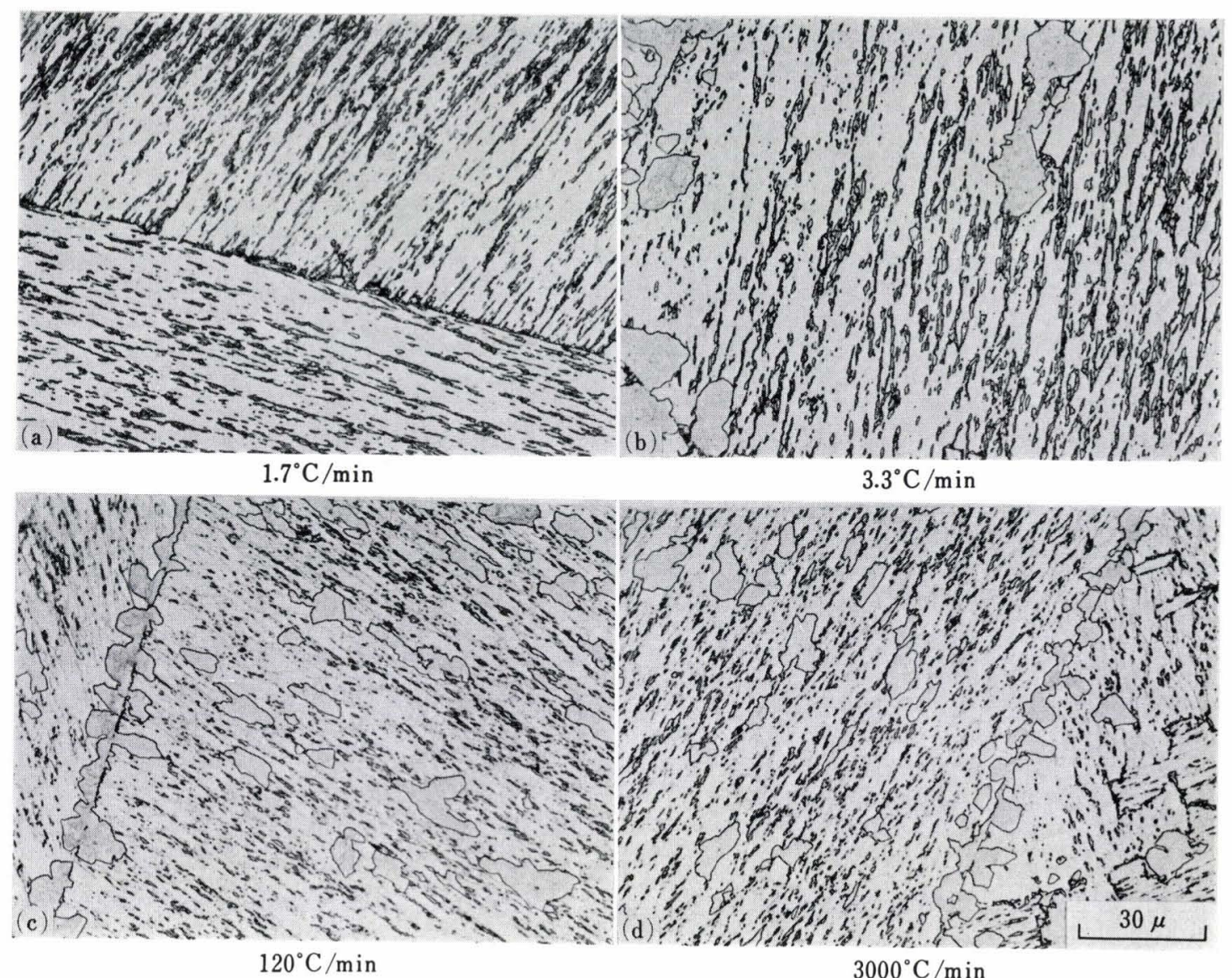

Photo. 5. Microstructures of specimens quenched from $700^{\circ} \mathrm{C}$ on the way of austenitizing (Optical micrograph)

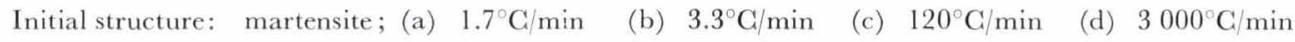

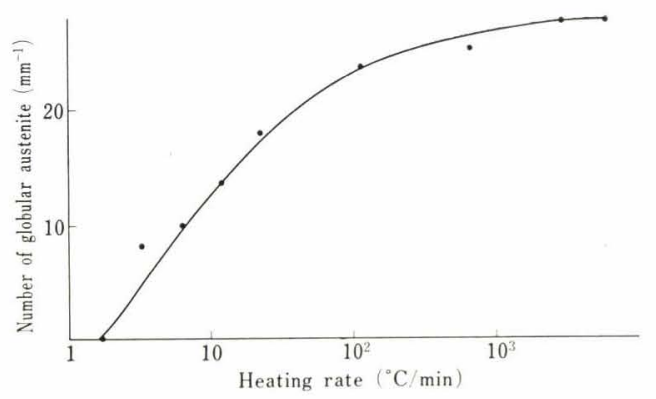

Fig. 2. Number of globular austenite as a function of heating rate

Table 4. Chemical composition of cementite just below $\mathrm{A}_{\mathrm{C} 1}$ temperature (wt \%)

\begin{tabular}{c|ccc}
\hline $\begin{array}{c}\text { Heating rate } \\
\left({ }^{\circ} \mathrm{C} / \mathrm{min}\right)\end{array}$ & $\mathrm{Mn}$ & $\mathrm{Ni}$ & $\mathrm{Fe}$ \\
\hline \multirow{2}{*}{3000} & 0.50 & 3.50 & 96.00 \\
& $(1.00)$ & $(1.00)$ & \\
120 & 1.63 & 3.26 & 95.11 \\
& $(3.26)$ & $(0.92)$ & \\
12 & 1.66 & 2.24 & 96.10 \\
& $(3.32)$ & $(0.63)$ & \\
3.3 & 2.32 & 2.47 & 95.21 \\
\multirow{2}{*}{1.7} & $(4.64)$ & $(0.69)$ & \\
& 2.09 & 1.54 & 96.37 \\
& $(4.18)$ & $(0.43)$ & \\
\hline
\end{tabular}

Figures in parenthesis: $(\mathrm{Mn}, \mathrm{Ni})_{\text {cem }} /(\mathrm{Mn}, \mathrm{Ni})_{\text {matrix }}$

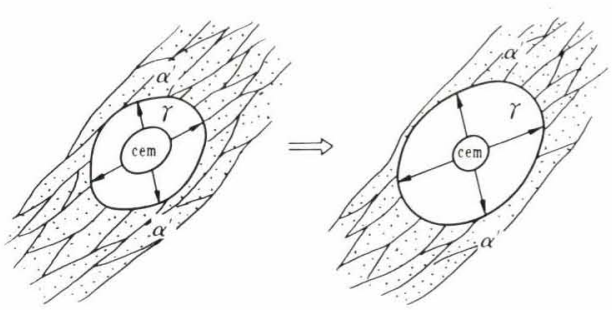

Initial structure: martensite

$\gamma:$ austenite

cem: cementite

$\alpha^{\prime}$ : lath martensite

Fig. 3. Mechanism of the formation of austenite and the dissolution of cementite

of grain is given by

$$
R=\frac{\left(C_{2}-C_{1}\right)\left(C_{\mathrm{cem}}-C_{0}\right)}{\left(C_{\mathrm{cem}}-C_{2}\right)\left(C_{2}-C_{0}\right)} \cdot 2 D_{\mathrm{C}}^{r} \cdot t
$$

where,

$R:$ radius of austenite grain

$t$ : isothermal transformation time

$C_{\text {cem }}$ : carbon concentration in cementite at the $\mathrm{Fe}_{3} \mathrm{C} / \gamma$ interface

$C_{2}$ : carbon concentration in austenite at the $\mathrm{Fe}_{3} \mathrm{C} / \gamma$ interface

$C_{1}$ : carbon concentration in austenite at the $\gamma / \alpha$ interface

$C_{0}$ : carbon concentration in ferrite at the $\gamma / \alpha$ interface

$D_{\mathrm{C}}^{r}$ : diffusion coefficient of carbon in austenite. 
Comparing the empirical Eq. (1) obtained in the present work with Eq. (2), growth parameter $K$ is represented by

$$
\kappa=\left\{2 D_{\mathrm{C}}^{\gamma}\left(C_{2}-C_{1}\right)\left(C_{\text {cem }}-C_{0}\right) /\left(C_{\text {cem }}-C_{2}\right)\left(C_{2}-C_{0}\right)\right\}^{1 / 2}
$$

Using the values of $D_{\mathrm{c}}^{r}, C_{\mathrm{cem}}, C_{2}, C_{1}$, and $C_{0}$ measured by Wells ${ }^{13)}$ and Aaronson ${ }^{14)}$ growth parameter $K$ can be calculated, and the results are shown in Table 5. As seen from Table 5, the measured values are in a good agreement with the calculated values. From these results, it may be concluded that globular austenite grains are formed by the diffusional reverse transformation and that the rate of growth is controlled by the diffusion of carbon in austenite.

The measured values of growth parameters are dependent on initial microstructures and are smaller in tempered martensitic structure than in martensitic and bainitic structures (Fig. 1, Table 5). In relation to these phenomena, Judd, ${ }^{11)}$ Heckel, ${ }^{15)}$ and Molinder ${ }^{16)}$ found that the rate of dissolution of cementite in the austenitizing process of steels in annealed conditions decreases by the presence of an alloying element. This means that the alloying element segregating to cementite changes the kinetic rate-controlling step or alters the boundary conditions. Recently Hillert attempted to analyse the effect of alloying element on the growth of individual austenite grain by using the data obtained by Judd and was led to the conclusion that the growth of austenite grain is also governed by the rate of carbon diffusion in the presence of cementite enriched with alloying elements.

Based upon the concept developed by Hillert, it can be explained that the small growth parameter in tempered martensitic structure is due to the decrease of the effective carbon gradient in austenite grain as a result of segregation of manganese to cementite by tempering at $600^{\circ} \mathrm{C}$ for $40 \mathrm{hr}$.

\section{Mechanism of Formation of Acicular Austenite}

The characteristics of acicular austenite grains formed in the early stage of austenitization are summarized as follows.

(1) The lengthwise direction is nearly parallel to the martensite or bainite lath boundaries (Photo. 3).

(2) The formation of acicular austenite grains does not accompany the dissolution of cementite (Photo. 3).

(3) Most of acicular austenite grains formed in a prior austenite grains have nearly the same orientation, and $\mathrm{K}-\mathrm{S}$ relationship exists between acicular austenite and martensite (Photo. 4).

In relation to the above result, Kunitake et al. ${ }^{17)}$ recently found that the orientations of retained austenite grains in a $9 \% \mathrm{Ni}$ steel are nearly the same in region of parallel sided martensite laths. Their result is basically in agreement with that of present work. Furthermore D'Yachenko showed by using a high temperature X-ray diffraction method that austenite grains formed on passing over the $\mathrm{A}_{\mathrm{C} 1}$ temperature in a $0.6 \% \mathrm{C}$ steel have texture maxma of $(111)_{\gamma} / /(110)_{\alpha}$ orientation.
Table 5. Comparison between measured and calculated growth parameters

\begin{tabular}{|c|c|c|c|}
\hline \multirow{2}{*}{$\begin{array}{c}\text { Reaction } \\
\text { temp. } \\
\left({ }^{\circ} \mathrm{C}\right)\end{array}$} & \multicolumn{2}{|c|}{$\begin{array}{c}\text { Growth parameter } K \\
\left(\mathrm{~cm} \cdot \mathrm{sec}^{-1 / 2}\right)\end{array}$} & \multirow{2}{*}{$\begin{array}{l}\text { Diffusion } \\
\text { coefficient of } \\
\text { carbon in } \\
\left.\text { austenite } \mathrm{D}_{\mathrm{C}}^{r}{ }^{14}\right) \\
\left(\mathrm{cm}^{2} \cdot \mathrm{sec}^{-1}\right)\end{array}$} \\
\hline & Measured & Calculated & \\
\hline 700 & $\begin{array}{l}1.5 \times 10^{-4}(\mathrm{M}, \mathrm{B}) \\
0.5 \times 10^{-4}(\mathrm{~F} / \mathrm{Cem})\end{array}$ & $0.8 \times 10^{-4}$ & $0.55 \times 10^{-8}$ \\
\hline 720 & $\begin{array}{l}2.0 \times 10^{-4}(\mathrm{~B}) \\
1.3 \times 10^{-4}(\mathrm{~F} / \mathrm{Cem})\end{array}$ & $1.0 \times 10^{-4}$ & $0.78 \times 10^{-8}$ \\
\hline
\end{tabular}

On the basis of those results, it is concluded that the formation of acicular austenite grains in the early stage of austenitization is martensitic reverse transformation obeying $\mathrm{K}-\mathrm{S}$ orientation relationship.

\section{Conclusions}

The process of the formation of austenite in the early stage of reverse transformation was studied in a low-carbon low alloy steel with acicular structures such as martensite, bainite, and tempered martensite. Main results are as follows.

(1) Austenite grains are divided into two types: one is globular and the other is acicular.

(2) Globular austenite grains are formed accompanying the dissolution of cementite, the rate-controlling step being the diffusion of carbon in austenite.

(3) Acicular austenite grains are formed by the martensitic reverse transformation obeying Kurdjumov-Sachs orientation relationship and have nearly the same orientation in a prior austenite grain.

\section{Acknowledgements}

The authors wish to thank Prof. J. Takamura for his useful discussions and advices, Dr. S. Nagashima and Dr. M. Nagumo for his careful preview of the manuscript.

\section{REFERENCES}

1) R. A. Grange: Trans. ASM, 59 (1966), 26.

2) R. A. Grange: U. S. Patent, No. 3178324 (1965).

3) R. Homma: Tetsu-to-Hagané, 53 (1967), 195.

4) R. Homma: Tetsu-to-Hagané, 54 (1968), 898.

5) M. Baeyertz: Trans. ASM, 30 (1942), 458.

6) A. E. Nehrenberg: Trans. AIME, 188 (1950), 162.

7) E. Kula and M. Cohen: Trans. ASM, 46 (1954), 727

8) D. Webster and G. B. Allen: JISI, 200 (1962), 520.

9) S. S. D'Yachenko and G. V. Fedrov: The Physics of Metal and Metallography, 18 (1964), 68.

10) R. Homma: Tetsu-to-Haegané, 58 (1972), 119.

11) R. R. Judd and H. W. Paxton: Trans. AIME, 242 (1968), 206.

12) M. Hillert, K. Nilsson, and L. E. Torndagl: JISI, 209 (1971), 49.

13) C. Wells, W. Batz, and R. F. Mehl: Trans. AIME, 188 (1950), 553.

14) H. I. Aaronson, H. A. Domian, and G. M. Pound: Trans. AIME, 236 (1966), 768.

15) R.W. Heckel and H. W. Paxton: Trans. AIME, 218 (1960), 799.

16) G. Molinder: Acta Met., 4 (1956), 565.

17) T. Kunitake and S. Watanabe: Tetsu-to-Hagané, 58 (1972). S545. 